Original Research Paper

\title{
Properties of Edible Film Produced using Combination of Collagen Extracts of Bligon Goatskin with Glycerol
}

\author{
${ }^{1}$ Muhammad Irfan Said, ${ }^{2}$ Yuny Erwanto and ${ }^{3}$ Effendi Abustam \\ ${ }^{1}$ Lab. of Animal By-Products Processing Technology, \\ Faculty of Animal Science, Hasanuddin University, Jl. Perintis Kemerdekaan Km.10, Makassar, Indonesia \\ ${ }^{2}$ Lab. of Leather, Waste and By-Products Technology, \\ Faculty of Animal Science, Gadjah Mada University, Jl. Fauna 3 Bulaksumur, Yogyakarta, Indonesia \\ ${ }^{3}$ Lab. of Meat dan Egg Processing Technology, \\ Faculty of Animal Science, Hasanuddin University, Jl. Perintis Kemerdekaan Km.10 Makassar, Indonesia
}

Article history

Received: 05-10-2016

Revised: 08-12-2016

Accepted: 19-12-2016

Corresponding Author: Muhammad Irfan Said Lab. of Animal By-Products Processing Technology, Faculty of Animal Science, Hasanuddin University, Jl. Perintis

Kemerdekaan Km.10,

Makassar, Indonesia

Fax (+62-411) 587217

Email: irfan.said@unhas.ac.id

\begin{abstract}
Edible films are one of packaging products that environmental friendly. Edible films can produce from the by-products of the slaughtering of livestock locally. Edible films used as materials packaging of foodstuff to protect food products of contamination of air, light, lipid, dissolved substances and microorganisms. One of the main advantages of edible film packaging is a natural character, so it can consume together with such food products. The purpose of this study was to evaluate the properties of edible film that produced from a combination of collagen extracts from glycerol as a plasticizer. The study was using collagen extract produced from materials of goatskin, Bligon types and ages 2-2.5 years as the main material and glycerol as ingredients plasticizer. Methods of this study were using experiment design with completely randomized pattern unidirectional the design. Three concentrations of glycerol applied, namely: $80 \%$; $90 \%$ and $100 \%$ (of the total extract collagen in the mix) combined with $10 \%(\mathrm{w} / \mathrm{v})$ extract collagen. The results showed that the difference concentration of glycerol that used in the mix effect in the thickness, tensile strength and elongation, but no significant on the solubility, water vapor transmission rate (WVTR) as well as $\mathrm{a}_{\mathrm{w}}$ values of edible films. The study implication was the application $F_{1}$ formula $(10 \mathrm{~g}$ $(10 \%)$ of extract collagen solid $+8 \mathrm{~g}$ of glycerol $(80 \%)+100 \mathrm{~mL}$ of distilled water) generating properties of edible films better.
\end{abstract}

Keywords: Edible Film, Collagen Extract, Plasticizer, Glycerol, Goatskin

\section{Introduction}

Bligon goat is one of the local livestock resources in Indonesia. One by-product of slaughtering the goat is the skin. Information sources related to the utilization of goatskin as a raw material for food packaging are still lacking. One of type of food packaging that environmental friendly was edible film. One of the advantages of edible film as the packaging material is can be consumed along with the product, so that no waste. Edible films need to be developing as an effort to create an environment zero waste.

In the formation, process of edible film requires a precise formulation in order to form a mass that is able to function properly. Edible film formation influenced by the type and composition of the constituent materials.
One of using collagen as an edible film today is as a packaging in the meat industry (Wang et al., 2015). The use of whey protein combined with glycerol also been developed as a packaging material (Perez et al., 2016). During this time, the manufacture of edible film comes from of starch, whereas, the basic ingredient of the protein has not been widely used. Edible films of three types of material (glycerol, starch and gum nuts) developed as a composite packaging material for fruit products (Saberi et al., 2016). The use of essential oils incorporated to carrageenan as material for edible film developed by Soni et al. (2015) as the packaging material in the chicken patties product.

In principle, the edible film serves to inhibit the process of mass transfer. In this case the factors related with: (1) moisture, (2) oxygen, (3) carbon dioxide, (4) 
aroma, (5) lipid and (6) other solutes. This is doing to protect the food from the invasion of water vapor and oxygen (Liu and Han, 2005). One of the benefits of edible film is environmentally friendly ( $\mathrm{Kim}$ and Ustunol, 2001; Simelane and Ustunol, 2005). One of protein source material that be used is collagen potentially. Collagen has some important functional properties, namely: (1) the gel strength, (2) time of gelling, (3) the melting temperature, (4) viscosity, (5) viscosity, (6) texture and (7) water content. Some properties of surface tension owned by the of collagen, namely: (1) the shape and stability, (2) emulsion, (3) protection of colloids, (4) the shape and stability of the foam, (5) form of films and (6) adhesion and cohesion. The properties of edible film related to the nature and formulation of the materials used. The combination of protein extract collagen with plasticizer (glycerol) allows undertaken produce the right combination. The use of plasticizer considered to improve the properties of edible film. This is doing through interaction process between the polymer chains making up the protein with a plasticizer (Brody, 2005). The addition of plasticizer in a film is very important. Plasticizer has very small volatile molecules. When added to the polymer material, it will form intermolecular attractive force. This will increase the volume of free bonds (Kokoszka et al., 2010).

Plasticizer plays an important role as a "barrier" interactions between molecules and increase the number of molecules that are free (Mali et al., 2004) as well as weaken the strength of intermolecular bonds in the polymer chain in the opposite (Gounga et al., 2007). Edible film is a thin layer formed from materials suitable for consumption (Krochta and Johnson, 1997). To prevent the loss of water molecules during the storage process, the required packaging material with properties better (Krochta et al., 1994). Some previous researchers had been incorporate of materials such as proteins, polysaccharides or fat (wax) in making edible film formulation (Caner et al., 1998). So, the use of materials of protein considered. This is because the properties of the resulting edible film showed better results (Klahorst, 1999).

Extract collagen from the group of proteins combined with glycerol from the group of fatty accordance exact formulation is very important to improve the quality and properties of edible film. The study aimed to evaluate the properties of edible film that produced using collagen extract combinated with glycerol as a plasticizer.

\section{Materials and Methods}

\section{Research Materials}

This study was using the main ingredient of goatskin, male, type of Bligon, age of 1.5-2 years, glycerol (brataco chemika) as a plasticizer, distilled water, aluminum foil, clip plastic, solution of $\mathrm{NaCl} 40 \%$ (w/v) and silica gel. The equipment was used in this study, namely: teflon plate round with diameter $22 \mathrm{~cm}$, analytical balance (Sartorius TE 214S), digital waterbath (Memmert WNB7-45), digital oven (Memmert), glass beaker, beakers, funnel, glass stirrer, thermometer, cutter knives, scissors and pipette of volume $100 \mathrm{~mL}$ (Pyrex), tube acrylic with diameter of $45 \mathrm{~mm}$ and height of 21 $\mathrm{mm}$ and a desiccator.

\section{Research Methods}

\section{Preparations Process of Making Collagen Extract}

A total of three skin sheet of goat of Bligon types, male, prepared to be processed further became collagen extract. Methods of hydrolysis of extract collagen performed in stages (Ockerman and Hansen, 2000). Goatskin weighed and washed, for further immersion in a solution of lime $\left(\mathrm{CaCO}_{3}\right)$ for $2 \mathrm{~h}$. Goatskin further neutralized with $\mathrm{HCOOH}$ solution to achieve a $\mathrm{pH}$ of 7-7.5. After the neutralization process followed by cutting into a size of $3 \times 3 \mathrm{~cm}$. Skin pieces are then composited until homogeneous and then stored in a refrigerator at a temperature of frozen $\left(-18^{\circ} \mathrm{C}\right)$ to prevent bacterial contamination.

A total of $400 \mathrm{~g}$ of goat skin as raw materials put in $\mathrm{CH}_{3} \mathrm{COOH} 0.5 \mathrm{M}$ solution for $96 \mathrm{~h}$. at a temperature of $5-10^{\circ} \mathrm{C}$. Goatskin transferred into a $500 \mathrm{~mL}$ tube erlenmeyer then added with distilled water on the ratio 1: 1. The extraction process was doing in a water bath for $9 \mathrm{~h}$ at a temperature of $55-70^{\circ} \mathrm{C}$. The extraction process consists of three phases, the first phase $(3 \mathrm{~h})$ at a temperature of $55-60^{\circ} \mathrm{C}$. The second phase $(3 \mathrm{~h})$ used the temperature of $60-65^{\circ} \mathrm{C}$ and the third phase $(3 \mathrm{~h})$ at a temperature of $65-70^{\circ} \mathrm{C}$. The results of the product of three stages of the process and then done the screening process (filtration) and homogenized. Results of filtration product obtained liquid extract collagen. The collagen extract dried on $70^{\circ} \mathrm{C}$ for $2 \mathrm{~h}$ and then cooled in a refrigerator on temperature of \pm $5-10^{\circ} \mathrm{C}$ for $30 \mathrm{~min}$. Further, the results of the fraction dried in an oven at a temperature of $55^{\circ} \mathrm{C}$ for $18-20 \mathrm{~h}$ to obtain solid collagen extract products. Extract collagen packed in plastic packaging.

\section{Preparation Process of Edible Film Solution}

Edible film formulation done by using a combination of extracts collagen solid (protein) with glycerol (fat). The total of $10 \mathrm{~g}$ of solid collagen extract dissolved in $100 \mathrm{~mL}$ of distilled water $(10 \% \mathrm{w} / \mathrm{v})$ and then homogenized. The use of glycerol applied three levels, namely: $\mathrm{F} 1=80 \% ; \mathrm{F} 2=90 \%$ and $\mathrm{F} 3=100 \%$, where, percentage of glycerol based on the amount of extract collagen used in the mix, namely $(\mathrm{F} 1=80 \% \times 10 \mathrm{~g}=8 \mathrm{~g}$ of glycerol); $(\mathrm{F} 2=90 \% \times 10 \mathrm{~g}=9 \mathrm{~g}$ of glycerol) and (F3 = 
$100 \% \times 10 \mathrm{~g}=10 \mathrm{~g}$ of glycerol). Based on these calculations means that three levels mixed formulations, namely:

- $\quad F_{1}=10 \mathrm{~g}$ of extract collagen solid $+8 \mathrm{~g}$ of glycerol $+100 \mathrm{~mL}$ of distilled water

- $\quad \mathrm{F}_{2}=10 \mathrm{~g}$ of extract collagen solid $+9 \mathrm{~g}$ of glycerol $+100 \mathrm{~mL}$ of distilled water

- $\quad \mathrm{F}_{3}=10 \mathrm{~g}$ of extract collagen solid $+10 \mathrm{~g}$ of glycerol $+100 \mathrm{~mL}$ of distilled water

\section{Process of Making Edible Film}

Three beaker glass sizes $250 \mathrm{~mL}$ were prepared. Three formula of solution (F1, F2 and F3) made in the glass beaker. The process of making edible film was using casting techniques (Carvalho et al., 2007; Sobral et al., 2001). Each glass beaker containing a solution of edible film (F1, F2 and F3) then put into a water bath and heated at $70^{\circ} \mathrm{C}$ for 45 min while stirring. The particles of solid collagen extract and glycerol homogenized. Edible film solution poured on the cast in hot conditions. Teflon dried in oven at a temperature of $55^{\circ} \mathrm{C}$ for $18-20 \mathrm{~h}$ until forming a thin layer on the cast. Teflon removed from the oven and placed at room temperature for approximately $10 \mathrm{~min}$. Gradually, the film opened using a blunt knife to prevent damage. The film wrapped in klip plastic and put in a desiccator to be tested.

\section{Method of Analysis}

Thickness (mm). The value of the film thickness was measure by using a micrometer (Digimetic Micrometer Mitutoya) (Kim et al., 2002). Film placed between clamps of micrometer and subsequently measured at random at 5-7 different places. The average value of the measurement results later counted.

Tensile strength (MPa). Tensile strength values measured using Universal Mechanical Testing Machine (Zwick/Z 0.5) (Kim et al., 2002). Model of test samples prepared as in Fig. 1. The assay samples using the width of $5 \mathrm{~mm}$, while a thickness of the film is determined from the average thickness of the measurement results. Speed of testing machine is $10 \mathrm{~mm} / \mathrm{min}$ with a distance between clamps is $50 \mathrm{~mm}$. Tensile strength values $=F_{\max }$ /A, where $F_{\max }$ is the maximum pull force of edible film sample until to break up $(\mathrm{N})$; $\mathrm{A}=$ wide of film area $\left(\mathrm{mm}^{2}\right)(($ length $(\mathrm{l}) \times$ width $(\mathrm{w}))$.

Elongation at break (\%). Elongation measurements performed in conjunction with a tensile strength test using Mechanical Universal Testing Machine (Zwick/Z 0.5). The test sample made as in Fig. 1 (Kim et al., 2002). Elongation is the length of the length of the film early. Elongation at break (\%). = Lc-Lo/Lo $\times 100 \%$, where Lo = initial length of the film $(\mathrm{mm}) ; \mathrm{Lc}=$ length of the samples edible film after being drawn up dropping out (mm).
Solubility (\%). Solubility is one of the physical properties of edible film that shows the percentage of the dry weight of the dissolved after immersion in water for 24 h (Gontard et al., 1992; Fakhouri et al., 2004). Film to be analyzed cut to the size of $2 \times 2 \mathrm{~cm}$ and then wrapped with filter paper. Film samples and filter paper dried at a temperature of $105^{\circ} \mathrm{C}$ for $24 \mathrm{~h}$. Film samples and filter paper weighed separately (for the determination of the weight of the dry film (W1). Soaking done $24 \mathrm{~h}$ at a temperature of $28^{\circ} \mathrm{C}$ and during the immersion process occasional stirring. The sheets of film and filter paper dried at a temperature of $105^{\circ} \mathrm{C}$ for $24 \mathrm{~h}$ to determine the weight of the film is not soluble in water (W2). Solubility $=\mathrm{W}_{1}-\mathrm{W}_{2} / \mathrm{W}_{1} \times 100 \%$, where $\mathrm{W}_{1}=$ weight of dry film initially $(\mathrm{g}) ; \mathrm{W}_{2}=$ weight of dry film after immersion $(\mathrm{g})$.

Water Vapor Transmission Rate $\left(\mathrm{g} \cdot \mathrm{H}_{2} \mathrm{O} \cdot \mathrm{m}^{-2} \cdot \mathrm{h}^{-1}\right)$. This value determined by gravimetric method (Xu et al., 2005). A acrylic tube with diameter $45 \mathrm{~mm}=4.5 \mathrm{~cm}(\mathrm{r}=$ $2.25 \mathrm{~cm}=0.0225 \mathrm{~m}$ ) and height $21 \mathrm{~mm}$ was used as a measuring tool. Film sample to be tested was placed on the top of tube containing $10 \mathrm{~g}$ of silica gel blue $(\mathrm{RH}=$ $0 \%$ ). The acrylic tube containing a sample of the film then put in a desiccator. A container was placed in a desiccator containing a saturated salt solution $(\mathrm{NaCl})$ $40 \%(\mathrm{w} / \mathrm{v})(\mathrm{RH}=75 \%)$ at a temperature of $25^{\circ} \mathrm{C}$. The water vapor diffused through the film absorbed by the silica gel so will increase the weight of the gel silica. Acrylic tubes weighed every hour for $7 \mathrm{~h}$. Finally, the data were then calculated using linear regression equation (slope should be calculated). WVTR = Slope of weight gain tube $(\mathrm{g} / \mathrm{h})(\mathrm{S}) /$ Total of Area Film (TAF) $\left(\mathrm{m}^{2}\right)$ (A), where: $\mathrm{S}$ is the value of $\mathrm{b}$ (slope) and a (intercept) the regression equation $(y=a+b x)$; Total Area Film $(\mathrm{TAF})\left(\mathrm{m}^{2}\right)(\mathrm{A})=\left(\pi . \mathrm{r}^{2}\right)=3.14 \times(0.0225)^{2}=0.00159 \mathrm{~m}^{2}$, where $r=$ diameter of film $=0.0225 \mathrm{~m}$.

Activity water. The determination of the water activity $\left(\mathrm{a}_{\mathrm{w}}\right)$ was conducted by using the tool $\mathrm{a}_{\mathrm{w}}$ meter (decagon Divice Pullman WA 99163, USA). A total of 1 $\mathrm{g}$ of film samples placed on the cylindrical container. The container is then placed on the bottom of $a_{w}$ meter finally, value of $\mathrm{a}_{\mathrm{w}}$ can be determined.

\section{Design of Study and Data Analysis}

The experiment conducted experimentally using a Completely Randomized Design (CRD) One-way pattern as the basic design. The parameters observed, namely: Thickness, tensile strength, elongation, Water Vapor Transmission Rate (WVTR) and activity water $\left(\mathrm{a}_{\mathrm{w}}\right)$ value. Data were analyzed using analysis of variance with the help of statistical program SPSS version 15.0. The experiment showed the real effect and further performed the real difference test with Duncan'S Multiple Range Test (DMRT) at the level of 5\% (Steel and Torrie, 1991). 




Fig. 1. Model of sample pieces of edible film to test the tensile strength and elongation at break

\section{Results and Discussion}

\section{Thickness}

The film thickness were affects the properties of edible film. Differences in concentrations of materials was used in the mixture will produce edible film with a thickness that varies. Results of analysis of variance of data in Fig. 2 shows that the differences in the level of glycerol was applied in combination collagen-glycerol extract showed significant effect to the properties of edible film thickness.

The number increased glycerol concentration in the mixture shows the real effect in increasing the thickness of the edible film. This happens because of the addition of the amount of polymer in the composition of edible film (Garcia et al., 2000; Tapia-Blacido et al., 2005). The concentration of dissolved solids in the mixture affects the thickness of edible film. This happened because of the greater concentration of solids, the structure of the edible film be thicker as well. Moreover, in the composition of the collagen extract and glycerol also contains high organic compounds (Talja et al., 2007).

The molecular structure of the collagen extract and glycerol can undergo a process of interaction. This is because the glycerol molecule is hydrophilic molecules with smaller form (Gontard et al., 1993). This molecule is very easy to enter in between the protein chains that make up the structure of collagen. Furthermore, these molecules will bind to form hydrogen bonds between the amide groups on the protein structure. The thickness of the edible film made in the range of 0.253 to $0.315 \mathrm{~mm}$. Edible film thickness increased with increasing use of glycerol as a plasticizer in combination collagen extractglycerol (Zhang and Han, 2006b).

\section{Tensile Strength}

Tensile strength is one of the physical properties of edible film closely related to the chemical structure of edible film. These properties determined by the type of edible film forming materials that will affect the nature of the structural cohesion edible film (Gontard et al., 1993).
Results of analysis of variance of data in Fig. 3 shows that, the difference in concentration of glycerol, that was apply show significant effect on the value of tensile strength of edible film. Increased of collagen concentration in the solution be causes reduction of tensile strength value of edible film. This is caused by the film matrix have destabilize as consequent increasing of concentration in the structure of the protein component hydrophilic of edible film. Glycerol has hydrophilic properties, which can cause the bending properties of edible film. Therefore, it can affect the value of tensile strength edible film (Gontard et al., 1993).

The tensile strength of edible film is the range from 2.277 to $5.265 \mathrm{MPa}$. Increased use of plasticizer can lower tensile strength edible film. Glycerol is one of plasticizer have applied widely to the manufacture of edible film because plasticizer has hydrophilic properties (McHugh and Krochta, 1994; Gennadios et al., 1998).

\section{Elongation at Break}

Elongation at break is the change in length of the edible film after given the maximum tensile force to break up edible film compared to the length at first. Results of analysis of variance of data in Fig. 3 shows that increased levels of glycerol show a significant influence on increasing the elongation properties of edible film. Edible film structure is a matrix formed by the interaction ties, such as hydrophobicity, hydrogen and disulfide. Edible film formed with a collagen concentration is higher, will increase the interaction between the ties. This causes the protein molecular bond stronger (Gennadios et al., 1998). Enhancement of the amount of plasticizer glycerol will increase the elongation and elastic modulus of the edible film. Plasticizer glycerol has a textural effect that can increase the flexibility of the protein matrix. This causes elongation of the edible film also increased (Reed et al., 1998). In addition, the plasticizer has the plasticity effect to produce high elongation (Lim et al., 1999). 


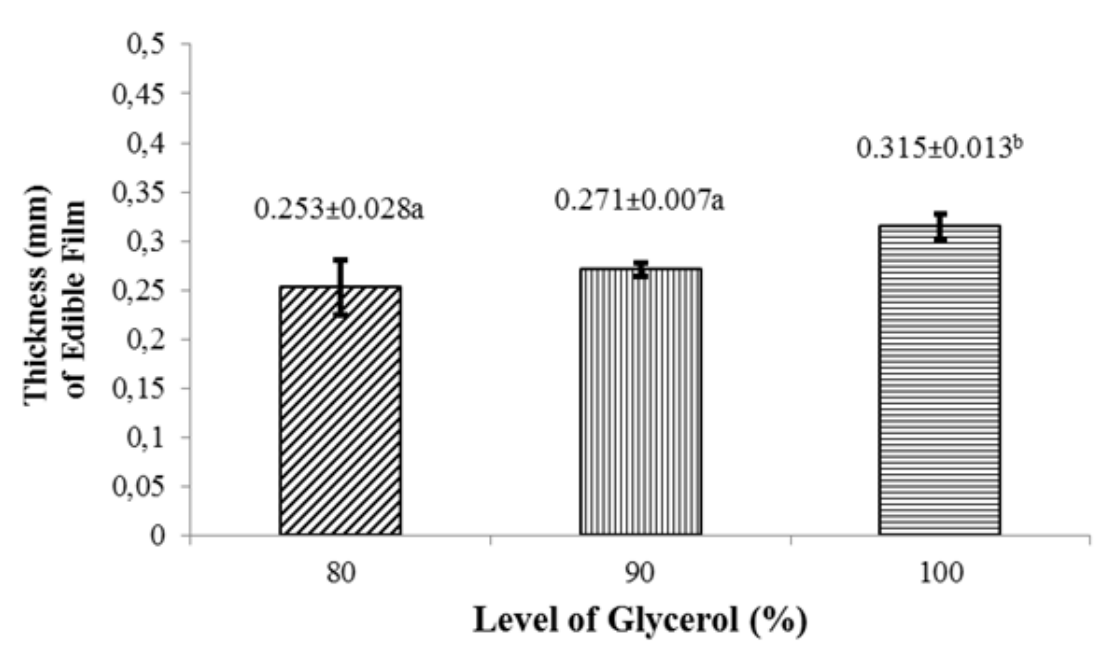

Fig. 2. Thickness value $(\mathrm{mm})$ of edible film between collagen extract combined with glycerol on the different concentrations

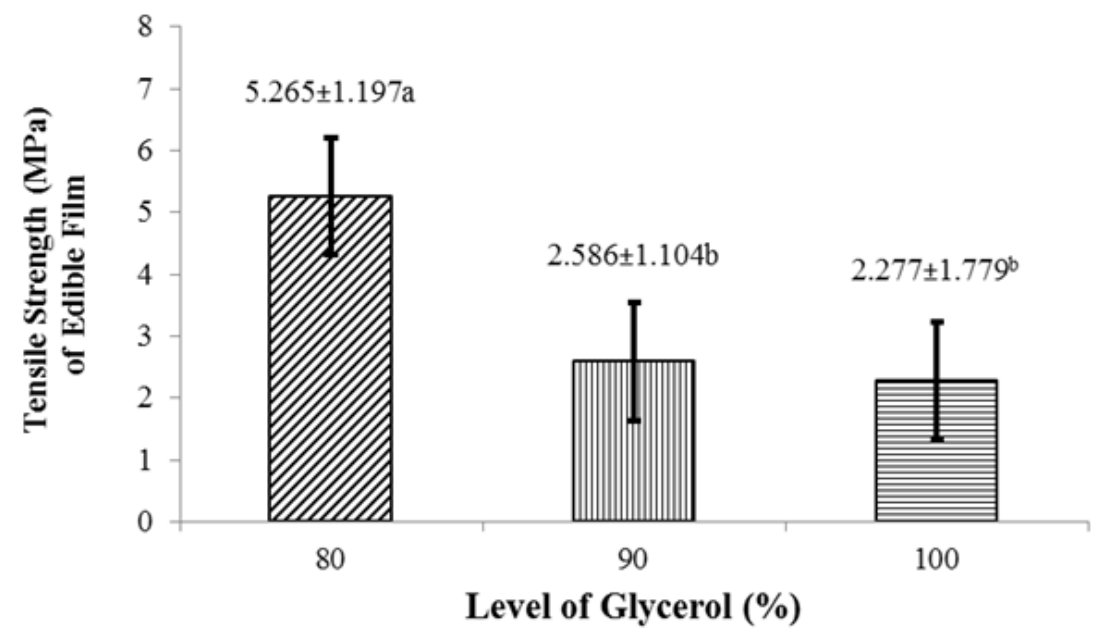

Fig. 3. Tensile strength value (MPa) of edible film between collagen extract combined with glycerol on the different concentrations

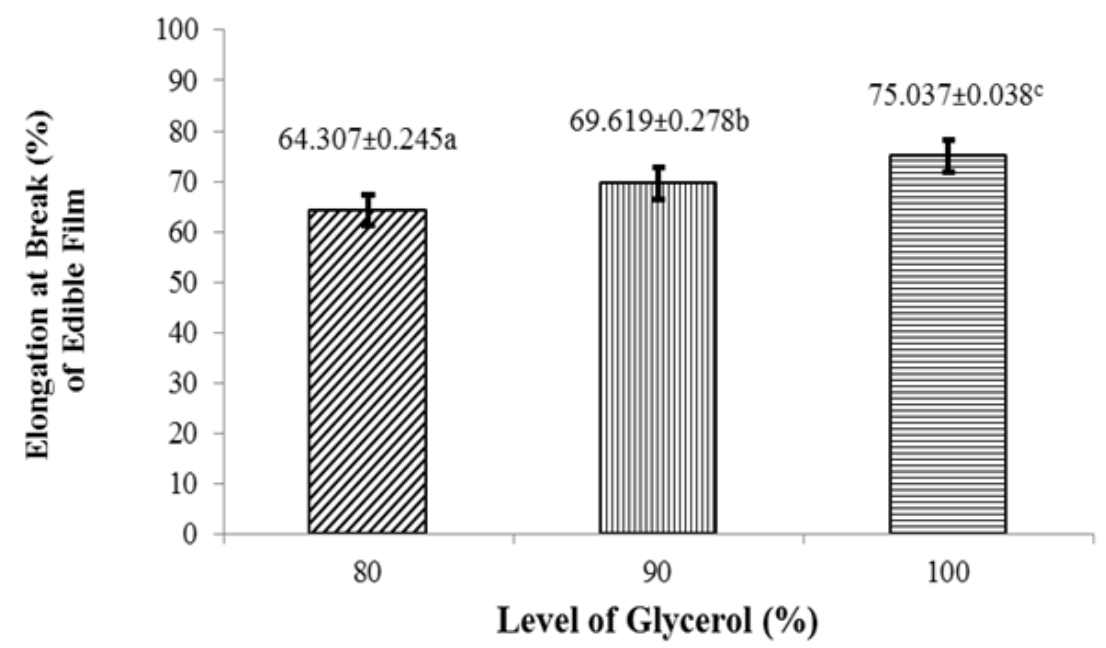

Fig. 4. Elongation at break (\%) value of edible film between collagen extract combined with glycerol on the different concentrations 


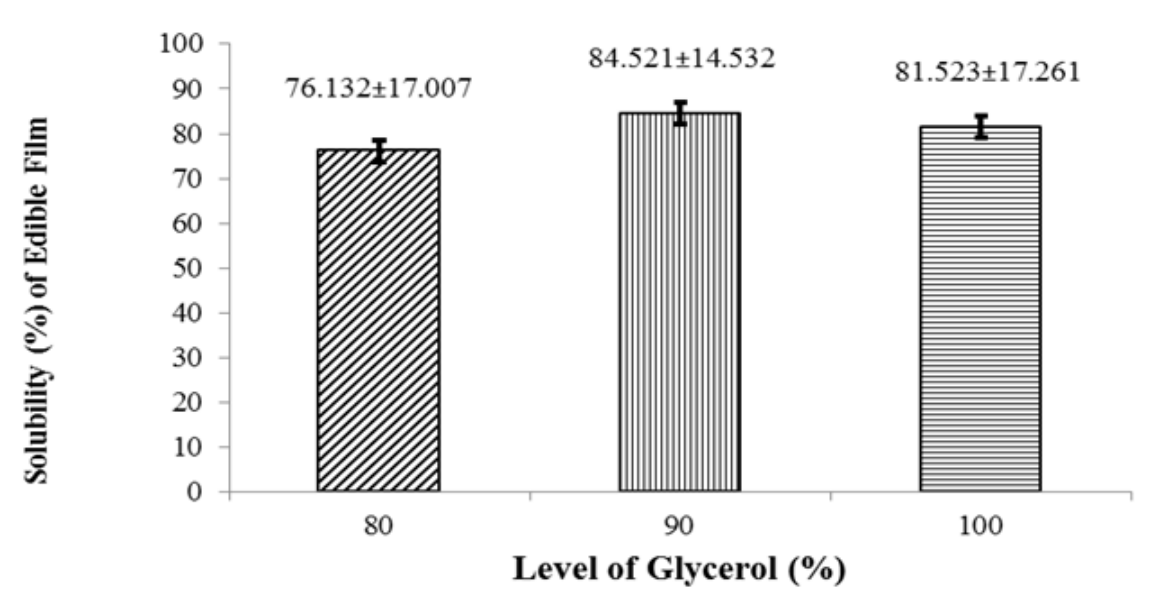

Fig. 5. Solubility (\%) value of edible film between collagen extract combined with glycerol on the different concentrations

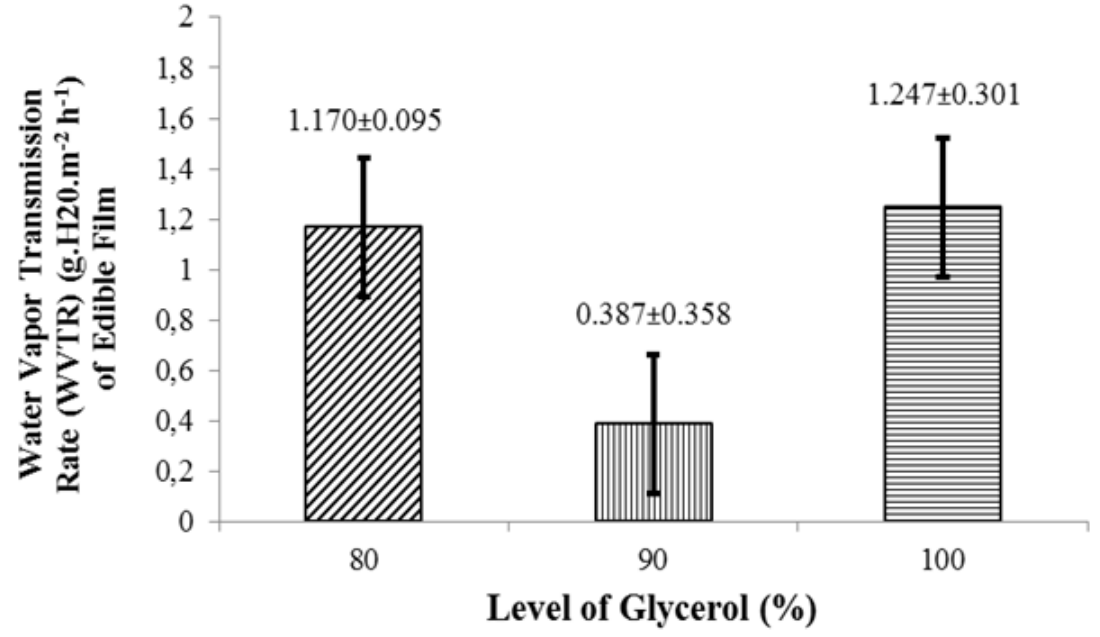

Fig. 6. Water Vapor Transmission ate (WVTR) $\left(\mathrm{g} \cdot \mathrm{H}_{2} \mathrm{O} \cdot \mathrm{m}^{-2} \cdot \mathrm{h}^{-1}\right)$ value of edible film between collagen extract combined with glycerol on the different concentrations

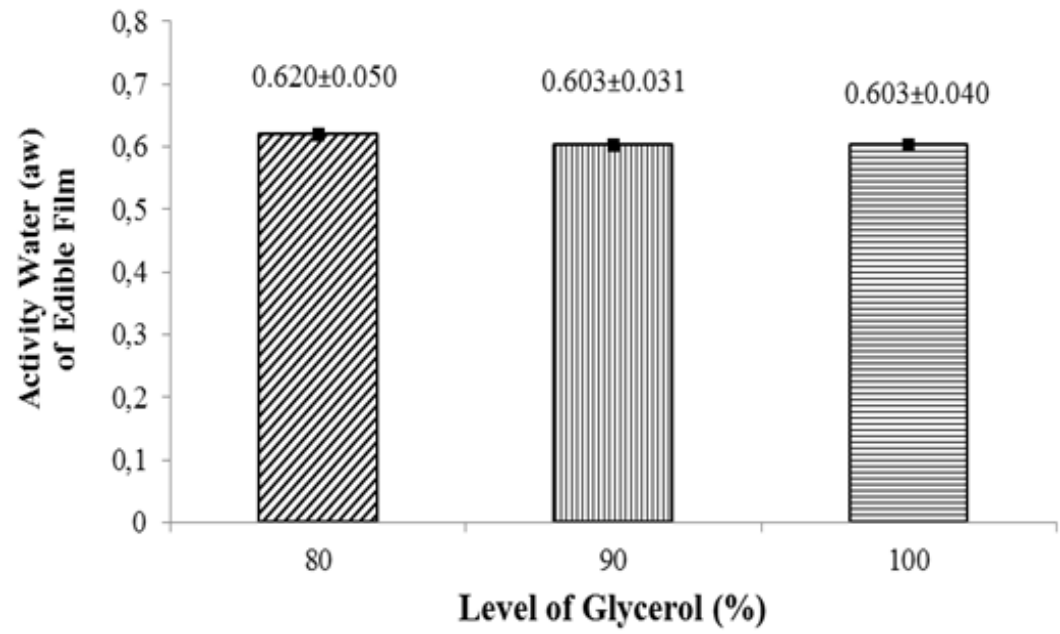

Fig. 7. Activity water $\left(\mathrm{a}_{\mathrm{w}}\right)$ value of edible film between collagen extract combined with glycerol on the different concentrations 


\section{Solubility}

Solubility is one of the physical properties of edible film that shows the percentage of the dry weight of the dissolved after immersion in water for $24 \mathrm{~h}$ (Gontard et al., 1992; Fakhouri et al., 2004). The results of the data in Fig. 4 show that, increased concentration of glycerol in the manufacture of solution of edible film no significant on solubility values of edible film. The addition of plasticizer in the solution of edible film will be cause decrease bond of intermolecular and intermolecular drastically. Increased concentrations of plasticizer will give the effect of space between the molecules that widening (Bozdemir and Tutas, 2003; Mendieta-Taboada et al., 2007). This can lead to increased solubility of edible film, including the disulfide bond (S-S) (Perez-Gago and Krochta, 1999).

\section{Water Vapor Transmission Rate}

One of the most important functional properties of the edible film is its ability to control the mass transfer, mechanical protection and related to the sensory value. The results of the data in Fig. 5 show that, increased levels of glycerol showed no significant effect on the Water Vapor Transmission Rate (WVTR) of the edible film. Several previous studies have pointed out the similarities of properties between the thickness with the permeability on the hydrophilic edible film (Liu and Han, 2005).

Increasing concentrations of plasticizer of glycerol can be increasing the flexibility of edible film and the Water Vapor Transmission Rate (WVTR) (Navarro-Tarazaga et al., 2008; Bourtoom et al., 2006). The use of plasticizer lead to changes in the physical and functional properties of edible film, namely: (1) increase the flexibility, sensitivity and moisture and then (2) the functional properties. Plasticizer reduction will be affect: (1) biopolymer chains adjacent to each other, (2) sensitivity to happen outside of water and (3) the flexibility of the material (Bergo and Sobral, 2007).

\section{Activity Water $\left(a_{w}\right)$}

Water activity $\left(a_{\mathrm{w}}\right)$ plays an important role in the process of packaging of food products. This measurement aims to determine the stability of the product of edible film during the storage process. As packaging materials, edible film expected to protect the packaged product.

Results of analysis of variance of data in Fig. 6 and 7 show that increased of glycerol concentration was not significant on the properties of edible film. According to Nelson and Cox (2000), collagen has a number of hydrophilic amino acids contained in the protein component. Glycine is one of the hydrophilic amino acids in the collagen structure which has the largest composition of the molecular bonds (approximately $35 \%$ ). value of $a_{w}$ indicates a measure that states the status of the amount of water in an energy system, in which water molecules can interact directly with component materials of protein (Bell and Labuza, 2000).

\section{Conclusion}

Differences in concentrations of glycerol that combined with the extract from collagen in the production process of edible film have significant effect on the properties of edible film such as: thickness, tensile strength and elongation at break, but no significant effect on the solubility, WVTR and activity water $\left(\mathrm{a}_{\mathrm{w}}\right)$ value. The combination formula for $\mathrm{F}_{1}(10 \mathrm{~g}(10 \%)$ of extract collagen solid $+8 \mathrm{~g}$ of glycerol $(80 \%)+100 \mathrm{~mL}$ of distilled water showed the properties of edible film better $F_{2}$ and $F_{3}$ related to the thickness, tensile strength and elongation at break parameter. The properties of edible film was using the formula $F_{1}$ same with $F 2$ and $F 3$ for the solubility, WVTR and $a_{w}$ parameters. The use of collagen extracts, as a source of protein will improve the properties of edible film, so, the combination of the use of the extract from collagen with glycerol as plasticizer considered to improve the properties of edible film.

\section{Acknowledgement}

The authors would like to thank to the Ministry of Research, Technology and Higher Education on financial support through the Research Grants program for students Doctoral Program. The authors also thanked the head of Food Technology Laboratory and Chemistry Laboratory of Gadjah Mada University, Yogyakarta, on the use of laboratory facilities.

\section{Author's Contributions}

Muhammad Irfan Said: Wrote the manuscript and designed the experiments.

Yuny Erwanto: Wrote the manuscript (reseach methods, discussion, grammar and spelling checking).

Effendi Abustam: Designed the experiments and assisted in data analyzed.

\section{Ethics}

This article is original and has not been published or presented elsewhere. All the authors have approved the manuscript and agree with submission to this journal. There are no conflict interest to be declare.

\section{References}

Bell, L.N and T.P. Labuza, 2000. Practical Aspects of Moisture Sorption Isotherm Measurement and Use. 2nd Edn., AACC Egan Press, Egan, MN.

Bergo, P and P.J.A. Sobral, 2007. Effect of plasticizer on physical properties of pigskin gelatin films. Food Hydrocolloids., 21: 1285-1289.

DOI: 10.1016/j.foodhyd.2006.09.014 
Bourtoom, T., M.S. Chinnan, P. Jantawat and R. Sanguandeekul, 2006. Effect of plasticizer type and concentration on the properties of edible film from water-soluble fish proteins in surimi wash-water. Food Sci. Technol. Int., 12: 119-126.

Bozdemir, O.A. and M. Tutas, 2003. Plasticizer effect on water vapour permeability properties of locust bean gum-based edible films. Turk J. Chem., 27: 773-782.

Brody, A.L., 2005. Packaging. Food Tech., 59: 65-66.

Caner, C., P.J. Vergano and J.L. Wiles, 1998. Chitosan film mechanical and permeation properties as affected by acid, plasticizer and storage. J. Food Sci., 63: 1049-1053. DOI: 10.1111/j.1365-2621.1998.tb15852.x

Carvalho, R.A., P.J.A. Sobral, M. Thomazine, A.M.Q.B. Habitante and B. Giménez et al., 2007. Development of edible films based on differently processed Atlantic halibut (Hippoglossus hippoglossus) skin gelatin. Food Hydrocolloids., 22: 1117-1123. DOI: 10.1016/j.foodhyd.2007.06.003

Fakhouri, F.M., P.S. Tanada-Palmu and C.R.F. Grosso, 2004. Characterization of composite biofilms of wheat gluten and cellulose acetate phthalate. Brazillian J. Chem. Eng., 21: 261-264. DOI: $10.1590 / \mathrm{S} 0104-66322004000200016$

Garcia, M.A., M.N. Martino and N.E. Zaritzky, 2000. Lipid addition to improve barrier properties of edible starch-based films and coatings. J. Food Sci., 65: 941-947. DOI: 10.1111/j.1365-2621.2000.tb09397.x

Gennadios, A., T.H. McHugh, C.L. Weller and J.M. Krochta, 1994. Edible Coating and Film Based on Protein. In: Edible Coatings and Films to Improve Food Quality, Krochta, J.M., E.A. Baldwin and M.O. Nisperos-Carriedo, (Eds.), CRC Press, ISBN-10: 1420059629, pp: 234-236.

Gontard, N., S. Guilbert and J.L. Cuq, 1992. Edible wheat gluten films: Influence of the main process variables on film properties using response surface methodology. J. Food Sci., 57: 190-195.

DOI: $10.1111 /$ j.1365-2621.1992.tb05453.x

Gontard, N., S. Guilbert and J.L. Cuq, 1993. Water and glycerol as plasticizers affect mechanical and water vapor barrier properties of an edible wheat gluten film. J. Food Sci., 58: 190-195. DOI: $10.1111 / \mathrm{j} .1365-2621.1993 . t b 03246 . x$

Gounga, M.E., S.Y. Xu and Z. Wang, 2007. Whey protein isolate-based edible films as affected by protein concentration, glycerol ratio and pullulan addition in film formation. J. Food Eng., 83: 521-530. DOI: 10.1016/j.jfoodeng.2007.04.008

Kim, K.W., C.J. Ko and H.J. Park, 2002. Mechanical properties, water vapor permeabilities and solubilities of highly carboxymethylated starchbased edible films. J. Food Sci., 67: 218-222. DOI: $10.1111 /$ j.1365-2621.2002.tb11387.x

Kim, S.J. and Z. Ustunol, 2001. Thermal properties, heat sealability and seal attributes of whey protein isolate/lipid emulsion edible films. J. Food Sci., 66: 985-990. DOI: 10.1111/j.1365-2621.2001.tb08223.x
Klahorst, S., 1999. Credible edible films.

Kokoszka, S., F. Debeaufort, A. Hambleton, A. Lenart and A. Voilley, 2010. Protein and glycerol contents affect physico-chemical properties of soy protein isolate-based edible films. Innovat. Food Sci. Emerg. Technol., 11: 503-510. DOI: $10.1016 /$ j.ifset.2010.01.006

Krochta, J.M. and M. Johnson, 1997. Edible and biodegradable polymer film: Challenges and opportunities. J. Food Tech., 51: 61-74.

Krochta, J.M., E.A. Baldwin and M.O. NisperosCarriedo, 1994. Edible coatings and films to improve food quality. Pennsylvania, 2: 215-218.

Lim, L.T., M.A. Tung and Y. Mine, 1999. Barrier and tensile properties of transglutaminase cross-linked gelatin films as affected by relative humidity, temperature and glycerol content. J. Food Sci., 64: 616-622. DOI: 10.1111/j.1365-2621.1999.tb15096.x

Liu, Z. and J.H. Han, 2005. Film-forming characteristics of starches. J. Food Sci., 70: E31-E36. DOI: 10.1111/j.1365-2621.2005.tb09034.x

Mali, S., L.B. Karam, L.P. Ramos and M.V.E. Grossman, 2004. Relationships among the composition and physicochemical properties of starches with the characteristics of their films. J. Agric Food Chem., 52: 7720-7725. DOI: 10.1021/jf049225+

McHugh, T.H. and J.M. Krochta, 1994. Sorbitol- vs glycerol-plasticized whey protein edible films: Integrated oxygen permeability and tensile property evaluation. J. Agric. Food Chem., 42: 841-845. DOI: $10.1021 /$ jf00040a001

Mendieta-Taboada, O., P. José do, A. Sobral, R.A. Carvalho, A. Mônica and B.Q. Habitante, 2007. Thermomechanical properties of biodegradable films based on blends of gelatin and poly(vinyl alcohol). Food Hydrocolloids, 22: 1485-1492. DOI: 10.1016/j.foodhyd.2007.10.001

Navarro-Tarazaga, M.L., R. Sothornvit and M.B. PérezGago, 2008. Effect of plasticizer type and amount on hydroxypropyl methylcellulose-beeswax edible film properties and postharvest quality of coated plums (Cv. Angeleno). J. Agric. Food Chem., 32: 223-228. DOI: $10.1021 / \mathrm{jf801708k}$

Nelson, D.L. and M.M. Cox, 2000. Lehninger Principles of Biochemistry. 3rd Edn., Worth Publishers, New York, ISBN-10: 0716742217, pp: 1152.

Ockerman, H.W. and C.L. Hansen, 1999. Animal ByProduct Processing \& Utilization. 1st Edn., CRC Press, USA, ISBN-10: 1566767776, pp: 544.

Perez-Gago, M.B. and J.M. Krochta, 1999. Water vapor permeability of whey protein emulsion films as affected by pH. J. Food Sci., 64: 695-698. DOI: $10.1111 / \mathrm{j} .1365-2621.1999 . t b 15112 . x$

Perez, L.M., G.N. Piccirilli, N.J. Delorenzi and R.A. Verdini, 2016. Effect of different combinations of glycerol and/or trehalose on physical and structural properties of whey protein concentrate-based edible films. Food Hydrocolloids, 56: 352-359.

DOI: 10.1016/j.foodhyd.2015.12.037 
Reed, T., A.H. Barret, J. Briggs and M. Richardson, 1998. Texture and storage stability of processed beefsticks as affected by glycerol and moisture levels. J. Food. Sci., 63: 84-87. DOI: $10.1111 /$ j.1365-2621.1998.tb15681.x

Saberi, B., R. Thakur, Q.V. Vuong, S. Chockchaisawasdee and J.B. Golding et al., 2016. Optimization of physical and optical properties of biodegradable edible films based on pea starch and guar gum. Industrial Crops and Products, 86: 342-352. DOI: 10.1016/j.indcrop.2016.04.015

Simelane, S. and Z. Ustunol, 2005. Mechanical properties of heat-cured whey protein-based edible films compared with collagen casings under sausage manufacturing conditions. J. Food Sci., 70: E131E134. DOI: 10.1111/j.1365-2621.2005.tb07085.x

Sobral, P.J.A., F.C. Menegalli, M.D. Hubinger and M.A. Roques, 2001. Mechanical, water vapor barrier and thermal properties of gelatin based edible films. Food Hydrocolloids, 15: 423-432. DOI: $10.1016 / \mathrm{S} 0268-005 \mathrm{X}(01) 00061-3$

Soni, A., G. Kandeepan, S.K. Mendiratta, V. Shukla and A. Kumar, 2015. Development and characterization of essential oils incorporated carrageenan based edible film for packaging of chicken patties. Nutrit. Food Sci., 46: 82-95. DOI: 10.1108/NFS-05-2015-0065
Steel, R.G.D. and J.H. Torrie, 1991. Principle and Procedure of Statistics. 2nd Edn. International Book Company, Tokyo.

Talja, R.A., H. Helén, Y. H. Roos and K. Jouppila, 2007. Effect of type and content of binary polyol mixtures on physical and mechanical properties of starch-based edible films. Carbohydrate Polymers, 71: 269-276. DOI: 10.1016/j.carbpol.2007.05.037

Tapia-Blacido, D., P.J. Sobral and F.C. Menegalli, 2005. Development and characterization of biofilms based on amaranth flour (Amaranthus caudatus). J. Food Eng., 67: 215-223. DOI: 10.1016/j.jfoodeng.2004.05.054

Wang, W., Y. Zhang, Y. Ran and N. Yonghao, 2015. Physical crosslinkings of edible collagen casing. Int. J. Biol. Macromolecules, 81: 920-925. DOI: 10.1016/j.ijbiomac.2015.09.032

Xu, Y.X., K.M. Kim, M.A. Hanna and D. Nug, 2005. Chitosan-starch composite film: Preparation and characterization. Industrial Crops Products, 21: 185-192. DOI: 10.1016/j.indcrop.2004.03.002

Zhang, Y and J.H. Han, 2006. Mechanical and thermal characteristics of pea starch films plasticized with monosaccharides and polyols. J. Food Sci., 71: 109-118. DOI: 10.1111/j.1365-2621.2006.tb08891.x 